IRA-International Journal of Management \&

Social Sciences

ISSN 2455-2267; Vol.15, Issue 05 (Oct.-Dec, 2019)

Pg. no. 150-155.

Institute of Research Advances

http://research-advances.org/index.php/RAJMSS

QUARTERLY

A $\begin{aligned} & \text { Institute of } \\ & \text { Research } \\ & \text { Advances }\end{aligned}$

\title{
A Critical Discourse Analysis of Major Media Reports about the Issue of the China-US Trade
}

\author{
Wang Jiaying $^{1 *} \&$ Pan Cuiqiong ${ }^{2}$ \\ ${ }^{1,2}$ School of Foreign Studies, Yangtze University, Hubei, 434023 PRC China. \\ \# corresponding author \\ Type of Work: Peer Reviewed. \\ DOl: http://dx.doi.org/10.21013/jmss.v15.n5.p1 \\ How to cite this paper: \\ Jiaying, W., Cuiqiong, P. (2019). A Critical Discourse Analysis of Major Media Reports about the \\ Issue of the China-US Trade. IRA-International Journal of Management \& Social Sciences (ISSN \\ 2455-2267), 15(5), 150-155. doi:http://dx.doi.org/10.21013/jmss.v15.n5.p1
}

(C) Institute of Research Advances.

(cc) $\mathrm{BY}-\mathrm{No}$

This work is licensed under a Creative Commons Attribution-Non Commercial 4.0 International License subject to a proper citation to the publication source of the work.

Disclaimer: The scholarly papers as reviewed and published by the Institute of Research Advances (IRA) are the views and opinions of their respective authors and are not the views or opinions of the IRA. The IRA disclaims of any harm or loss caused due to the published content to any party.

Institute of Research Advances is an institutional publisher member of Publishers International Linking Association Inc. (PILA-CrossRef), USA. The institute is an institutional signatory to the Budapest Open Access Initiative, Hungary advocating the open-access of scientific and scholarly knowledge. The Institute is a registered content provider under Open Access Initiative Protocol for Metadata Harvesting (OAI-PMH).

The journal is indexed \& included in WorldCat Discovery Service (USA), CrossRef Metadata Search (USA), WorldCat (USA), OCLC (USA), Open J-Gate (India), EZB (Germany) Scilit (Switzerland), Airiti (China), Bielefeld Academic Search Engine (BASE) of Bielefeld University, Germany, PKP Index of Simon Fraser University, Canada. 


\begin{abstract}
Nowadays, CDA is widely used in news discourse because it can help people understand the implicit viewpoints in news discourse and grasp the true situation of news reports. As the main form of news discourse, media reporting is good intertextuality for CDA. Therefore, this paper, based on the theory of CDA, tries to discuss the implication of major media reporting about the issue of the China-US trade, from which the genre of media reporting here is also analyzed.
\end{abstract}

Keywords: Critical discourse analysis, China-US trade, ideology and genre of news discourse

Critical discourse analysis holds that any text is interpreted in different ways and it doesn't have only correct meaning. Once discourse is used in a specific context and associated with other structures, it may produce important ideological meaning. One of the tasks of critical discourse analysis is to analyze the possible understanding of discourse. Nowadays, with the rapid development of mass media, news discourse plays an increasingly important role in various social processes and its influence on people's thinking and behavior. However, news reports have never been absolutely objective and fair, and they are driven by the interests of various political groups and power groups. The analysis of the relationship between language, power and ideology in discourse is the medium connecting language and society, which is of practical significance to the analysis of news discourse. A better understanding of the theoretical basis and analytical methods of critical discourse analysis will help news readers to grasp the true situation of events in news discourse and its implicit ideology.

Therefore, this paper, based on the theory of CDA, tries to discuss the implication of major media reporting about the issue of the China-US trade, from which the genre of media reporting here is also analyzed.

\title{
1. Related theories of CDA
}

\subsection{Characteristics of CDA}

Critical discourse analysis (CDA) has been extensively studied in Western European linguistic circles from the late 1970 s to the early 1980 s and developed from critical linguistics. In China, the study of critical discourse analysis began in the 1990s, on behalf of the scholar Xin Bin and others led this academic trend. Fairclough \& Wodak (1997) summarize the main tenets of CDA as follows:1. CDA addresses social problems, 2. Power relations are discursive, 3. Discourse Constitutes Society and Culture, 4. Discourse does ideological work,5. Discourse is historical, 6. The link between text and society is mediated 7. Discourse analysis is interpretative and explanatory, 8. Discourse is a form of social action.

Therefore, CDA attaches great importance to the interaction between discourse and social structure. Because of this, Wu Hongyan (2008) believes that "through the critical analysis of public discourse, we can improve our ability to appreciate and criticize the use of language, and better cope with the 
increasingly widespread involvement of language in social life today".

\subsection{Genre Intertextuality and its ideology}

Discourse analysis regards discourse as discourse, discourse practice and social practice. In the process of generation, dissemination and acceptance of discourse, various discourses interweave with each other, forming the intertextuality of discourse. The intertextuality of news discourse is mainly manifested in the form of reporting. Reporting discourse is an important part of news discourse. It can not only enhance the authenticity of the report and show the objectivity of the report, but also convince the reader that the reporter does not mix his personal views (Xin Bin, 1998). However, because of the political position and economic interests, the news media can not achieve real objectivity and impartiality. When trying to retell discourse, it will conflict with the original discourse and imply the ideology of the reporters.

Modern mass media is the discourse medium between the official and the masses, trying to enable the public to accept official language communication more widely. In order to blur the boundary between the discourse of the narrator and the discourse of the person to be reported, the mass media also tends to use indirect speech and drown out the voice of the audience with the voice of the narrator.

\section{A case study of news discourse}

\subsection{Ideology reflected from different media reports about the China-US trade}

Critical discourse analysis focuses on social issues, revealing the ideology in the discourse, revealing the relationship between discourse and power, and understanding the construction of discourse and social culture.

As we know, the China-US trade war is becoming more and more intense. China and the United States are at a standstill in their economic development. Around this focus, countries have reported related events one after another. This study takes a series of reports from Chinese and English tripartite media as data and then uses CDA to explore the ideology implied in the mainstream media of various countries.

In the process of news reporting, in order to make the report objective and fair, the mass media will choose a large number of other people's words to reproduce. While attracting readers' attention, it also increases the objectivity of news, so that readers can more intuitively grasp the development trend of China-US trade war events. It aims to make people feel that the focus of events is closely related to public life, and to guide and control the ideology of newsreaders. In the collected text corpus, this paper uses the method of quantitative statistics to analyze the proportion of the existing forms of the reporting discourse in news discourse and the implicit ideology in the reporting discourse.

The three countries of China, the United States and the United States have reported on the recent development of the China-US trade war series from different standpoints. In order to prove the truthfulness and reliability of the news reports, it is inevitable to use other people's retelling discourse. 
Among them, there are 10 direct quotes from the official speeches, which are from Chinese government departments and US officials. With the development trend of China-US trade wars, the report uses these direct quotes to present the readers, attracting readers' attention and enhancing the persuasiveness of the report texts, making the reports appear objective and reliable.

While the mass media reported on the official initiatives of China and the United States, they also expressed their views and influenced on the development of events by trade research commentators and relevant people, thus publishing their own opinions. For example, the VOA news mentioned the impact of Chinese market suppliers and Chinese consumers in the United States after the trade war. They show that if the trade war continues, even if the consumers don't suffer the consequences, it will have an impact on the Chinese economy, affecting the public interest, and consciously guiding and controlling the ideology of the ordinary people.

\subsection{Genre reflected from different media reports about the China-US trade}

Critical discourse analysis (CDA) studies the surface of language (words, syntax, voice) in order to understand the deep meaning of the text and promote readers to truly understand the work. Fowler and others (1996) also pointed out that in critical discourse analysis, special attention should be paid to the ideological implications of transitivity, modality, transformation, classification and coherence.

In the selected series of news reports about the China-US trade, we can find the special usage of vocabulary and voice of language which reveals the relationship between language and ideology that is not easily perceived by people, and also reveals how the power stratum uses language to influence people's ideology to safeguard their own interests and existing social structures. Here are the analyses for some typical examples in the media reporting.

Example 1: China is expected to announce a series of trade measures in retaliation for the latest blunt American tariff hikes on Chinese goods. It's warning that its countermeasures will be of equal scale. (BBC)

Example 2 : China's finance ministry said the move was in reaction to U.S. tariffs on steel and aluminum imports announced in March. (VOA)

Example 1 and 2 are reported that the United Kingdom and the United States have responded differently to the US tariff policy in the United States. The United Kingdom and the United States have reported on China in different positions. The BBC uses retaliation to describe the behavior of the Chinese side. It is "retaliation and counterattack" to show that China is not humble when faced with pressure from the US, and it is straightforward to cope with obstruction and to fight for leadership. VOA is described by reaction with neutral words. The attitude of the Chinese side to the pressure on the US is also changing with the use of words, and it is in a passive weak position.

Example 3 : China is pursuing development at home while embracing the world. (Daily Telegraph)

Example 4 : China remains the world's biggest trader in goods, achieving a 9.7 per cent increase in 2018 and more than $\$ 4.5$ trillion in total value. Despite some frictions, China-US trade and economic 
cooperation show enormous potential and resilience. (Daily Telegraph)

The British Daily Telegraph quoted a series of figures showing the current state of China's economic development, and then commented on it, indicating the significance of the Chinese economy towards the development of the world economy. The report borrows the "embrace" as a real verb to express the significance of China's economic development to global economic growth. This paper describes the prospects of China's economic development by using "enormous potential and resilience", conveys the views and positions appreciated by the author, and guides readers to maintain confidence and support for China's economic development. The reader analyzes the modality system to understand his interpersonal function and comprehend the attitude and intention of the discourse.

Example 5 : The United States proposed to impose additional 10 percent tariffs on $\$ 200$ billion worth of Chinese goods on Tuesday and thus expanded the tariff war he launched by imposing 25 percent tariff on $\$ 34$ billion of Chinese imports on July 6. (China Daily News)

Example 6 :Hopefully, Trump will realize that the tariff war cannot "make America great again", instead it would isolate the US in the international community like never before. (China Daily News)

Example 5 China Daily News uses clear figures to objectively describe the fierce situation of the China-US trade war so that readers can intuitively understand the escalation and intensification of China-US trade competition, which will have a great impact on the lives of ordinary people. Example 6 News report uses the word "hopefully" from the Chinese side to express their deep expectations of US President Trump, hoping that he can realize in time that the China-US trade war is harmful to the development of both China and the United States and to the economic development of the world. The United States should pull back from the brink of the precipice in time and work with China to jointly develop world trade.

Fairclough (1992) proposes a three-dimensional framework for discourse research: discourse, discourse practice and social practice. Discourse is the language of social practice and he emphasizes that language practice is determined by society. The language itself is also a kind of social behavior, which is restricted by society, culture, politics, history, power, ideology and so on.

Through the above analysis, we believe that in the reading comprehension of news discourse, the genre strongly reveals the ideology implied by the reporter. When reading news discourse, readers can consciously critically understand the modality of the discourse and the transformation of discourse, paying attention to the author's writing intention and ideology. Discourse and power are closely related. In the current exchange of international relations, learn to grasp the news ideology to interpret the news.

\section{References}

[1] FAIRCLOUGH, N. Critical Discourse Analysis: The Critical Study of Language[M]. London: Longman, 1995.

[2] FAIRCLOUGH, N. Discourse and Social Change[M]. Cambridge: Polity Press, 1992.

[3] FAIRCLOUGH, N.\&WODAK,R. Critical discourse analysis[C]//.T.VAN DIJK(ed.) Discourse as 
Social Interaction. London:Sage, 1997

[4] Fowler N. On Critical Linguistics [M]. Conlthard. Lon-don: Routledge, 1996: 8.

[5] Xin Bin. A critical Analysis of reporting discourse in News discourse [J]. Beijing: foreign language Teaching and Research, 1998(2).

[6] Xin Bin. Comparative analysis of reporting methods and sources in China Daily and New York Times [J]. Foreign language and Foreign language Teaching, 2006(3)

[7] Zhu Yongsheng, Yan Shiqing, Miao Xingwei. Introduction to functional Linguistics [M]. Shanghai: Shanghai Foreign language Education Press, 2004: 137 - 138.

[8] Wei Zhongsheng. Dialogism of News discourse-based on critical discourse Analysis of RMB Exchange rate report [J]. Journal of Changsha University, 2012(4): 112-114.

[9] Yuan Chunming, Tian Hailong. Contrastive and critical Analysis of English and Chinese political discourses [J]. Journal of Tianjin Business School, 2001( 5): $51-53,60$.

[10] Shi Guang. A Review of critical discourse analysis [J]. Academic Forum, 2007(4):202-205. 